\title{
A Petition from P. Cair. Isid ${ }^{1}$ \\ P. Cair. Isid. 138, JE57419 - SR2644 \\ $15 \times 23 \mathrm{~cm}$ \\ 319 CE \\ Karanis (Kom Aushim)
}

\author{
Magdy A. I. Aly \\ Mansoura University \\ magdy@mans.edu.eg
}

\section{INTRODUCTION}

According to TM there are 500 archives dated between the $6^{\text {th }}$ century BCE and the $7^{\text {th }}$ century CE written in several languages (i.e. Greek, Latin, Demotic, Coptic and Arabic). The archive of Aurelius Isidoros son of Ptolemaios grandson of Pankratios "A.I.P.P" is the sixth in order according to the number of preserved documents (after Zenon son of Agreophon "1838 documents", Temple of Narmouthis: house of the ostraca "529", Heroninos, estate manager "452", Temple library of Tebtynis " 211 " and Kronion son of Apion head of the grapheion of Tebtynis "192"), where Aurelius Isidoros is " 175 ".

The archive of AIPP is getting its importance from the variety of the types of the documents and the indications of the several people mentioned in the archive, as well as the number of the preserved documents.

The Archive can be summarized as it mentioned in TM in the following points:

- It was found in Karanis in the house with dovecotes C35/37

\footnotetext{
${ }^{1}$ This papyrus was prepared to be edited as part of the International Seminar on the Cairo Papyri, sponsored by the Association Internationale de Papyrologues (AIP), in cooperation with the Egyptian Museum, the Center for the Tebtunis Papyri at the University of California, Berkeley (which digitized photographs originally taken several decades ago by the AIP's International Photographic Archive of Papyri), and the Institute for the Study of the Ancient World, New York University. Funding for the seminar was provided by the Tianaderrah Foundation and a private donor.
} 


\section{A Petition from P. Cair. Isid}

- It covers the period from 267 to $324 \mathrm{CE}$.

- Although AIPP is the central figure, not all texts relate to Isidoros himself.

- The documents of the archive have been published in the following publication: P. Cair. Isid 1-146; P. Merton 1 30; 31; 88-89; 91-92; P. Col. 7 124-125, 136-141, 169-171, 179-180; P.Mich. XII 626, 636; SB XII 10881; ZPE 172.173

- The archive has been written in Greek and 6 bilingual Greek-Latin documents.

From the Archive of AIPP, a short biography of can provide a wide angle of his activities, sufferings, relationships and the stemma ${ }^{3}$ of his family can be concluded in the short following lines:

- AIPP was born around the year $264 \mathrm{CE}^{4}$ and the latest.

He had six brothers: Pankratios, Isidoros, Peras, Palemon, Heron, Heras and Demetrios and one sister: Isidora.

- The earliest attestation is in P. Cair. Isid 99, Lease of Land, Karanis (Arsinoites), 29 Aug. 297.

- The latest attestation is being in P. Cair. Isid 76dupl, Petition to a Praepositus Pagi, Karanis (Arsinoites), 16. July 318.

- He was land-owner; in $299 \mathrm{CE}$ he owned $35 \frac{27}{64}$ arouras of royal and private land in Karanis and its territory ${ }^{5}$ and it is increased to be 140 arouras. As well as he was a tenant farmer and leasing land from residents of Karanis.

The archive contains 177 documents between 267 and $324 \mathrm{CE}$ :

- Receipts (64)

- Contracts (33)

- Petitions (31)

- Lists and accounts (18)

- Reports (11)

- Declarations (10)

- Official correspond (6)

- Private correspond (4)

It seems that AIPP was struggling with different types of people whether officials ${ }^{6}$ such the case of this document and P.Cair. Isid 68 in

2 van Minnen, Archaeology and papyrology, in Tradition and

transformation. Egypt under Roman rule, 2010, p. 465

${ }^{3}$ P. Cair. Isid., 1960, p. 6.

${ }^{4}$ See note on line 19, 20

${ }^{5}$ L. Koenen / S. Omar, 'P.Cairo Isid. 5', ZPE 11 (1973), p. 245-250 


\section{Magdy A. I. Aly}

which he charging the secretary of Karanis and his three associates, for nominating him to the office of chaff collector or other known people who destroyed his crops as a result of $\operatorname{arson}^{7}$ as it happened in $298 \mathrm{CE}$.

The petitions of the archive of AIPP have been edited within a period of time of 29 years are 26 documents $^{8}$. The officials to whom the petitions were addressed can be classified as follows:

Petition to a Praepositus Pagi $=7$ doc.

Petition to a Strategos $=5$ doc.

Petition to unknown $=4$ doc.

Petition to a Beneficiarius $=3$ doc.

Petition to a Prefect of Egypt $=3$ doc.

Petition to a Logistes $=1$ doc.

Petition to a Praepositus $=1$ doc.

Petition to a Praeses of Aegyptus Herculia $=1$ doc.

Petition to an eirenarches $=1 \mathrm{doc}$.

They can be deduced in the following table:

\begin{tabular}{|c|c|c|c|}
\hline Ser. & Pub. \# & Title & Date \\
\hline 1 & $\begin{array}{l}\text { P. Cair. Isid } 139- \\
\text { unpublished }\end{array}$ & 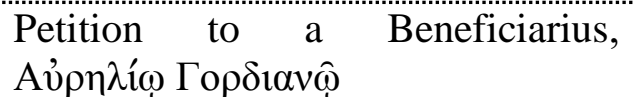 & 296 \\
\hline 2 & P. Cair. Isid 62 & 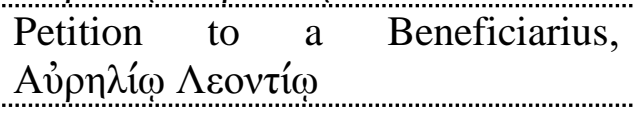 & \\
\hline 3 & P. Cair. Isid 63 & 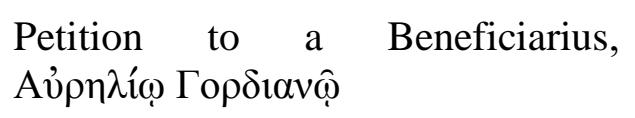 & 297 \\
\hline 4 & P. Cair. Isid 64 & \multirow{2}{*}{ 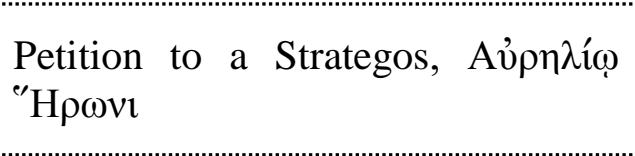 } & 298 \\
\hline 5 & P. Cair. Isid 65 & & $\begin{array}{l}298- \\
299\end{array}$ \\
\hline 6 & P. Cair. Isid 66 & \multirow{2}{*}{$\begin{array}{l}\text { Petition to a Prefect of Egypt, } \\
\text { Ai } \lambda{ }^{\prime} \omega t \text { Пov } \beta \lambda i \omega^{\prime}\end{array}$} & 200 \\
\hline 7 & P. Cair. Isid 67 & & 299 \\
\hline
\end{tabular}

${ }^{6}$ See note on line 8

${ }^{7}$ Cf. A.E. Hanson, 'A Petition and Court Proceedings: P.Michigan inv. 6060', ZPE 111 (1996), p. 175-176

${ }^{8}$ See Table and chart 


\section{A Petition from P. Cair. Isid}

\begin{tabular}{|c|c|c|c|}
\hline 8 & $\begin{array}{l}\text { P. Cair. Isid } 142- \\
\text { unpublished }\end{array}$ & Petition & 300 \\
\hline 9 & P. Cair. Isid 79 & 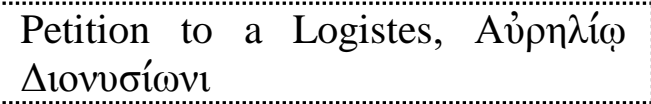 & $\begin{array}{l}301- \\
325\end{array}$ \\
\hline 10 & P. Cair. Isid 68 & Petition to a Praepositus Pagi, & $\begin{array}{l}309 \\
310\end{array}$ \\
\hline 11 & $\begin{array}{l}\text { P. Cair. Isid } 69 \\
\text { P. Cair. Isid } 70\end{array}$ & 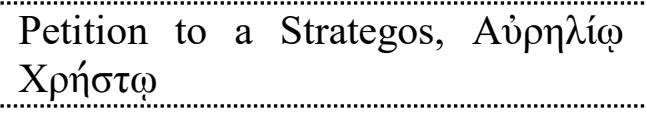 & 310 \\
\hline 13 & P. Cair. Isid 73 & $\begin{array}{l}\text { Petition to a Prefect of Egypt, } \\
\text { 'Iov } \lambda^{\prime} \omega \text { 'Iov } \lambda_{1} \alpha v \hat{\omega}\end{array}$ & 314 \\
\hline 14 & $\begin{array}{l}\text { P. Cair. Isid } 74 \text { - } \\
\text { dupl }\end{array}$ & 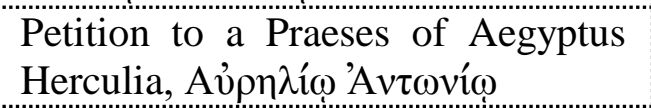 & 315 \\
\hline 15 & P.Mert.2.91 - dupl & Petition to the Strategos & \multirow[b]{2}{*}{316} \\
\hline 16 & P. Cair. Isid 75 & $\begin{array}{l}\text { Petition to a Praepositus Pagi, } \\
\text { Aủpn } \lambda \text { í } \Gamma \varepsilon \rho \text { covtí }\end{array}$ & \\
\hline 17 & $\begin{array}{l}\text { P. Cair. Isid } 76- \\
\text { dupl }\end{array}$ & 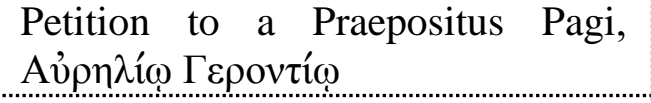 & \multirow{3}{*}{318} \\
\hline 18 & P.Col.7.169 & \multirow{2}{*}{ Petition for Recovery } & \\
\hline 19 & P.Col.7.170 & & \\
\hline 20 & P. Cair. Isid 138 & Petition probably to Strategos! & 319 \\
\hline 21 & P. Cair. Isid 77 & 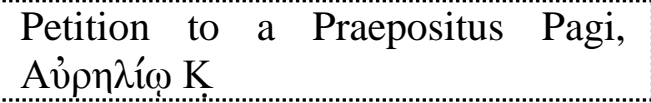 & 320 \\
\hline 22 & $\begin{array}{l}\text { P. Cair. Isid } 140- \\
\text { unpublished }\end{array}$ & Petition to a Praepositus Pagi & 323 \\
\hline 23 & P. Cair. Isid 78 & $\begin{array}{l}\text { Petition to a Praepositus Pagi, } \\
\Delta \text { tookó } \omega\end{array}$ & \multirow{3}{*}{324} \\
\hline 24 & P.Col.7.171 & Petition to the Praepositus Pagi & \\
\hline 25 & P.Mert.2.92 & Petition to the Praepositus & \\
\hline 26 & P. Cair. Isid 141 & $\begin{array}{l}\text { A draft of a Petition to an } \\
\text { eirenarches }\end{array}$ & $\begin{array}{l}276- \\
325\end{array}$ \\
\hline
\end{tabular}

This Incomplete oblong sheet of papyrus has a Light brown color and it is thin and of fine quality. The folds, breaks, frayed, misaligned and removed fibers have left the papyrus in an exceedingly bad condition and affect the legibility. The surface also marred by abrasion and darkened by discoloration in numerous parts. The right and lower edges are rather sliced 


\section{Magdy A. I. Aly}

by a sharp tool rather than regularly cut, most likely done by the dealer. The lower part of the left side is regularly cut. A big portion has been lost at the connective part between top and left sides. The papyrus has preserved the left margin is ca. $1.9 \mathrm{~cm}$, and lower margin is as vast as ca. $8.5 \mathrm{~cm}$. From the shape of the breaks of the papyrus it seems clearly that the papyrus was irregularly folded at least five vertical times, and four horizontal times. There are several lacunae in different shapes at the middle of the papyrus. A wide space of the papyrus is covered by dark blot probably of mud. The papyrus still needs conservation and cleaning, as well as some fibers need to be aligned. The papyrus has preserved 14 incomplete and 6 complete lines at the end of the text. The text has been written along with fibers in recto in black color ink with a fine pen.

The hand is of relatively small-sized cursive with frequent ligatures. Despite of the hand is neat and careful, there are some faulty orthography occurs in lines 8, 18, 19 and 20. It is fluent and has some calligraphic features. The hand is characterized by following letter characteristics:

Alpha usually formed in two loops that are facing left. Theta mostly is drawn small and contracted with a horizontal stroke from the middle used as a connective to the following letter. Chi is written with two crossed diagonal strokes sometimes with hooks on the top and bottom of left one and sometimes not. Epsilon is inconsistent, either lunate with attached tongue from the middle, or as a rather angular with small L-shape from the upper end, or formed without lifting the pen in a contracted ogee shape. Kappa is very distinguished with two vertical and sweeping strokes forming the Roman K. Iota when ligatured with previous letter it has a long descender and if not it is medium-sized equal ascender and descender. Omicron is always complete small circle and it is of an even size. Delta generally forms a ligature with the following letter; it sometimes has a hook on top of its vertex. Rho formed with almost round head and a short vertical stroke ends with serif. The tau is T-square with a serif at the left side of the bar. Upsilon is small Y Shape sometimes with a loop underneath. $X i$ formed as Roman $\mathrm{Z}$ shape with a loop in the junction of the base. The Interlinear spaces are even of ca. $0.4 \mathrm{~cm}$. The scribe has a tendency towards not leaving space between words. There is a diaeresis (trema) mark over the iota of ivo in line 19. There are no other abbreviations or other punctuation marks. The document dates back to the $1^{\text {st }}$ quarter of 4 th century, specifically $319 \mathrm{CE}^{9}$.

\footnotetext{
${ }^{9}$ The Info provided description by: Boak, Arthur E. R. / Youtie, Herbert Chayyim in the online description of AIP in the PN, and note on line 20
} 


\section{A Petition from P. Cair. Isid}

This document belongs to Karanis (modern Kom Ushim); Arsinoite nome (Herakleidou meris); Heptanomia region. This document represents a Petition from Aurelius Isidoros son of Ptolemaios to an official whose name and title are lost ${ }^{10}$, asking to be relieved of a liturgy. It is worthy to mention that the archive ${ }^{11}$ of Aurelius Isidoros son of Ptolemaios is currently exists in the following institutions:

Cairo, Egyptian Museum (156 documents)

New York, Columbia University (14 documents)

Ann Arbor, Michigan University, Library (8 documents)

Dublin, Chester Beatty Library (6 documents)

New York, New York University, Fales Library (1 document).

The archive covers a period of 57 years. It is an archive of the family of Aurelius Isidoros, rather than his personal archive. Actually many documents belong either to his father, or his brothers or even some other non-relatives people (Atisios, son of Hatres); yet A. Isidoros considers a central figure of this archive.

The verso is blank.

${ }^{10}$ See note on line 2

${ }^{11}$ See the online article published in 2013 by Karolien Geens in TM 


\section{Magdy A. I. Aly}

\section{TRANSCRIPTION}

$\rightarrow$

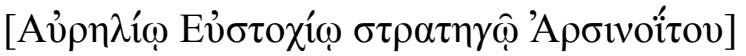

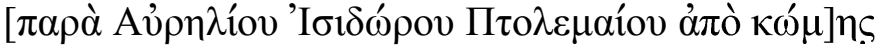

$$
\text { K } \alpha \rho \alpha-
$$

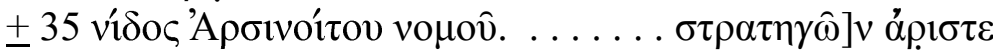

$4-$

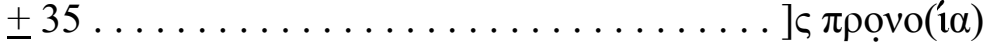

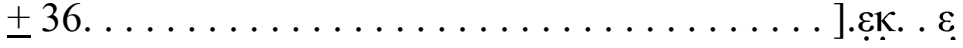

$\pm 35 \ldots \ldots \ldots \ldots \ldots \ldots \ldots \ldots \ldots \ldots \ldots \ldots \ldots \ldots \ldots \ldots$

\pm 35 .

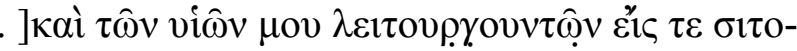

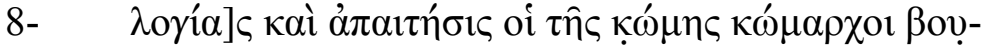

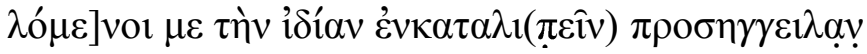

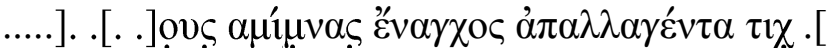

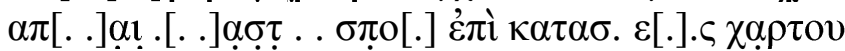

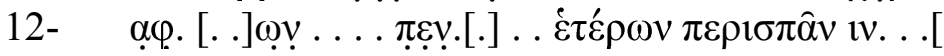

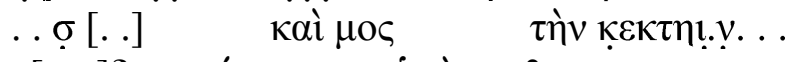


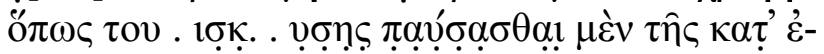

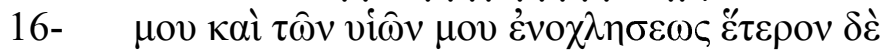

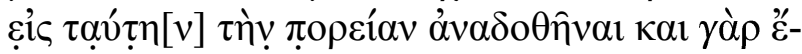

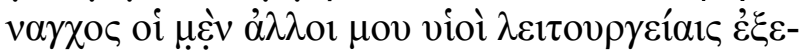

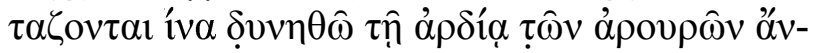

20- $\quad \theta \rho \omega \pi о \varsigma \pi \rho \alpha i ́ \sigma \beta v \varsigma, \alpha \sigma \chi 0 \lambda \alpha ́ \zeta \varepsilon เ v . \delta 1 \varepsilon v \tau u ́ \chi \varepsilon 1$.

\section{Corrections}

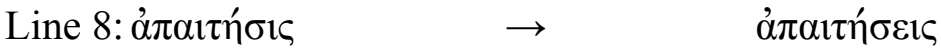

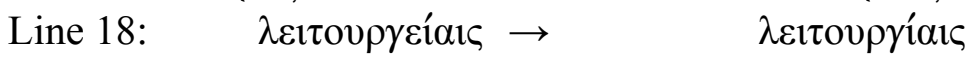

Line 19: $\quad$ iv $\alpha \quad \rightarrow \quad$ ív

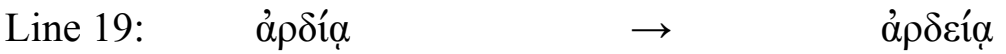

Line 20: $\pi \rho \alpha i ́ \sigma \beta v \varsigma \quad \rightarrow \quad \pi \rho \varepsilon \dot{\sigma \beta} \quad \rightarrow$ 


\section{A Petition from P. Cair. Isid}

\section{TrAnSLATiON}

[To Aurelius Eustochios, strategos of the Arsinoite nome, from Aurelius Isidoros, son of Ptolemaios, from the village of Karanis division of the Arsinoite nome......] O noblest of strategoi,

...demanding...

and although my sons were serving liturgies for both the office of sitologos and tax collector, the komarchs of the village want me to abandon my own statement, ....... just now release $\ldots . . \ldots \quad \ldots . .$. papyrus . ....of the others to molest ... come to you for the $\ldots \ldots$... $\ldots$ in order that the $\ldots . .$. to stop the troubles against me and my sons, to give up the other to this course and because of the past, on one hand my other sons present themselves for liturgies so that the old man may be able to engage working in the irrigation of the arouras. Farwell

\section{COMMENTARY}

Line 1-2: $\kappa \omega ́ \mu] n \varsigma ~ K \alpha \rho \alpha-$ although that the sigma is unclear as those in the rest of the document, it is still confirmed according to the constant formula of the archive.

As it is cited in all petitions of the archive of AIPP, the header of the text should be in the following formula: the official to whom the petition

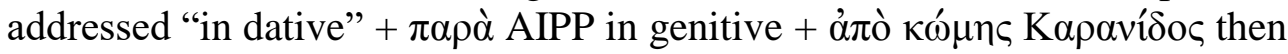

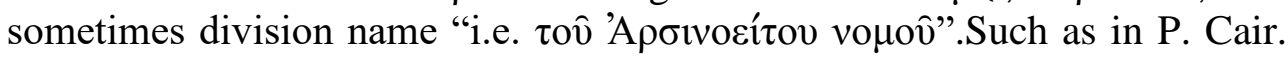
Isid 65, 67, 68, 69, 70, 74, 75, 76dubl and 79.

Although all these documents are addressed as petitions, only two documents (P. Cair. Isid 70 and 76dubl) that have a definite word (i.e. $\beta \imath \beta i \delta 10 v)$ indicating an apparent meaning of the content of the text.

Line $2 \sigma \tau \rho \alpha \tau \eta \gamma \hat{\omega}] \nu$ ápı $1 \sigma \tau \varepsilon$ : the average of the missing letters in this line are ca. 35; the formula of the provenance and the name of the official are enough to restore 28 letters and the other letters (ca. 8) are hard to figure out what they could be, where there is no specific phrase can be suggested at that part of the petition.

The word $\alpha \rho j \sigma \tau \varepsilon$ is cited twelve times, seven of them describing the strategos; three are unknown officials, one to the praepositos and one to hypomnematographos "scribe of the minister of finance", nevertheless still the word exclusively attested with the official Strategos. 


\section{Magdy A. I. Aly}

The Strategoi who were in office during the period from 310 to 320 are:

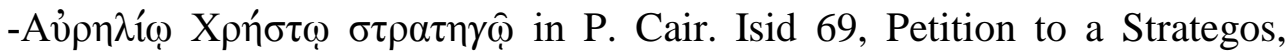

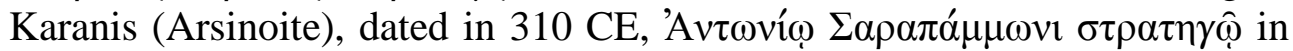
P. Cair. Isid 54, Receipt for the Price of Clothing, Karanis (Arsinoite), dated in 15. Jan. 314 CE.

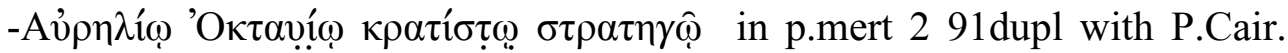
Isid. 74, Petition to the Strategos, Karanis (Arsinoite), dated in $316 \mathrm{CE}$ and

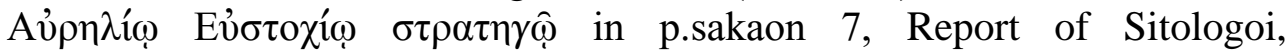
Theadelphia (Arsinoite), dated in $320 \mathrm{CE}$.

Hence, if the date was $319 \mathrm{CE}$ - and mostly it is -, the strategos to

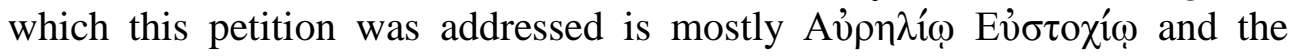
restoration of the header would be:

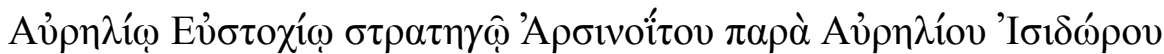

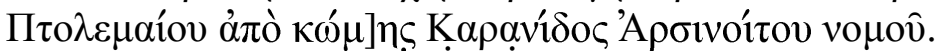

Accordingly, the header should be restored in the following formula:

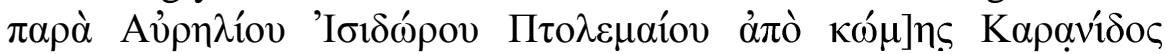

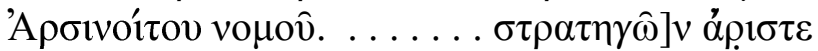

Line 3, 4, 5 and 6: these lines lost about 35-36 letters in the missing portion at the beginning of the first six lines. A word such as $\beta 1 \beta \lambda_{1} \delta^{\prime}$ iov (petition) was mostly written after the header of the petition (probably in line 3). The reading is a problematical; the word $\pi \rho v_{0}(i \alpha)$ "foresight, providence" at the end of line 3 is not definite, the sigma after the lacuna is doubtful, as well as the omicron after pi. Though, it stands a good restoration for the preserved letters. While the preserved letters at the end of line 4 are faded and illegible. Except for the illegible letter after the break, the letters at the preserved part of line 5 are more legible and might stand for a good restoration for the $\pi \alpha \nu \tau$ ò $\varsigma$. Only traces of faded letters at the preserved part of line 6 .

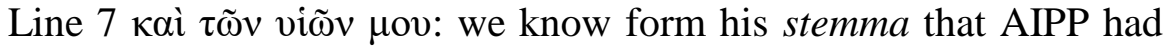
two sons: Patieis, who was acting as AIPP's agent for the payment of taxes on 294 CE (P.Ciar.Isid. 9) when he was 12 years old, he also was kephalaiotes in $315 \mathrm{CE}$ at the age of 29. According to the archive of AIPP Patieis must have been about twenty years older than his step-brother Peeous son of the second wife (Tales) of AIPP, who was thirteen years by 319 CE. Consequently, Patieis must have been 33 years old and Peeous must have been 13 years old when this petition was written; and surely they can be nominated for the liturgies the office of sitologos and tax collector. 


\section{A Petition from P. Cair. Isid}

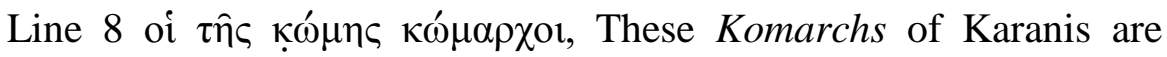
mostly: Aurelius Ariston, son of Serenus and Aurelius Germanus, son of Selpous who are mentioned in the archive around that date ${ }^{12}$. It seems clearly that AIPP had chronic troubles with them where from P. Cair. Isid 73 in which complain to the prefect of Egypt about the injustices being inflicted on the people of Karanis by the praepositus of the pagus and by the komarchs of Karanis that has been dated in 314 CE (5 years earlier to the current petition) which might lead to the reason by which the komarchs of Karanis have intentionally nominated him although he was "an old man" instead of his sons, who they of course younger and stronger, for liturgies.

Line 9 \& $v \kappa \alpha \tau \alpha \lambda \mathrm{l}(\pi \varepsilon \hat{\imath} v)$ "to abandon" the ending of this infinitive is abbreviated by a long horizontal stroke as it is scribed in Boak. AIPP is convincing the strategos that the komarchs are intentionally impairing his properties.

$\pi \rho \circ \sigma \eta \gamma \gamma \varepsilon i \lambda \alpha v$ "statement" the alpha is attached to the right leg of the lambda a part of it is washed out then traces of ink which is mostly is the connection of the alpha and $n u$.

Line 10 ...... The reading is a problematical as a result of the abrasion of ink and the severe tear of fibers. $\alpha \mu$ í

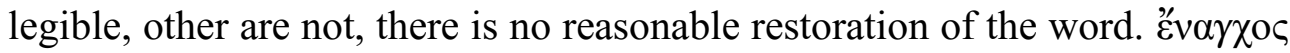
$\dot{\alpha} \pi \alpha \lambda \lambda \alpha \gamma \mathcal{\varepsilon}^{\prime} v \tau \alpha \tau \imath$. [ there is no a pattern construction with participle to figure out what is expecting afterwards. archive.

Line 11 x $\alpha \rho \tau$ ov "papyrus, roll, sheet" the word is hapax in the

Line 12 - $15 \pi \varepsilon \rho ı \sigma \pi \hat{\alpha} v$ "vex, disturb, molest" the infinitive shows what AIPP was exposed to by the komarchs. The reading generally is unclear and hard to construct an accurate phrase, but it is generally AIPP tries to concentrate on the ways by which the komarchs of Karanis persecute him.

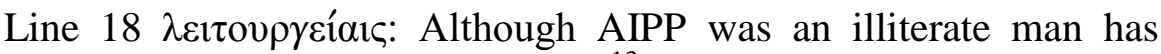
been assigned to the following ten Liturgies ${ }^{13}$ : In 298/299 was Kephalaiotes, 299/300 was Pediophylax, 300/301was Apaitetes, (301 to 304) was Collector of meat, 308/309 was Komarch, 309/310 was Sitologos, 310/311was Chaff collector, 313/314 was Tesserarius, 317 was replaced by the son of Tanouphis, probably because he elderly and called upon to

${ }^{12}$ Cf. P.Ciar.Isid 56, 57 and 58315 CE.

${ }^{13}$ Cf. Boak, 1956, p. 37-40; P. Cairo Isid., 1960, p. 11-17 


\section{Magdy A. I. Aly}

perform an ergasia and in 318 he was nominated to a liturgy, and he tried to evade it by an exchange of liturgies with Ptolemaios, a much younger man and finally in $319 \mathrm{CE}$ in this document he was nominated for another liturgy.

Line 19, 20 although the word ïv $\alpha$ has been attested nine times in the archive, it is cited only once with the trema in line 27; in P. Cair. Isid 77, Petition to a Praepositus Pagi, Karanis (Arsinoite), $320 \mathrm{CE}$; in the same Archive of Aurelius Isidoros. Yet the composition " $v \alpha \alpha \delta v \eta \theta \hat{\omega}$ " has been used once in another Petition to a Strategos, P. Cair. Isid 64, dated in 298 $\mathrm{CE})$.

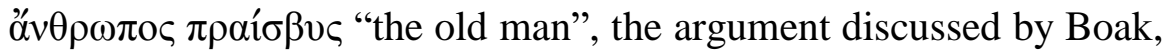
p. 394 shows a significantly confusion in the documents considering the age of AIPP. That can be concluded in the following table:

\begin{tabular}{|c|c|c|c|c|}
\hline Document & Date & Age & $319 \mathrm{CE}$ & DOB \\
\hline P. Cair. Isid 81 & $297 \mathrm{CE}$ & 35 & 57 & $262 \mathrm{CE}$ \\
\hline P. Cair. Isid 97 & $308 \mathrm{CE}$ & 37 & 48 & $271 \mathrm{CE}$ \\
\hline P. Cair. Isid 125 & $308 \mathrm{CE}$ & 40 & 51 & $268 \mathrm{CE}$ \\
\hline P. Cair. Isid 91 & $309 \mathrm{CE}$ & 45 & 55 & $264 \mathrm{CE}$ \\
\hline P. Cair. Isid 8 & $309 \mathrm{CE}$ & $40+$ & $51-55$ & $264-268 \mathrm{CE}$ \\
\hline
\end{tabular}

According to P. Cair. Isid 97, the age 48 is excluded by the year 319 $\mathrm{CE}$ as age of AIPP, where he is considered young to be called $\pi \rho \varepsilon \varepsilon \sigma \beta v \varsigma$. Since AIPP was replaced the liturgies twice: in P. Cair. Isid 123 and in P. Cair. Isid 82, by a private agreement during, the years 317-319 which reflects the incapability as a result of elderliness. As well as, P. Cair. Isid 91 and P. Cair. Isid 8 are indicating that he was in his fifth decade (specifically 41 - 45) which means that in $319 \mathrm{CE}$ he was in the sixth decade. Yet, P. Cair. Isid 91 is giving more specific age for AIPP (i.e. 45) which does not conflict with P. Cair. Isid 8. Hence, he mostly was 55 years old by $319 \mathrm{CE}$ and consequently he was born around or in in $264 \mathrm{CE}$. 


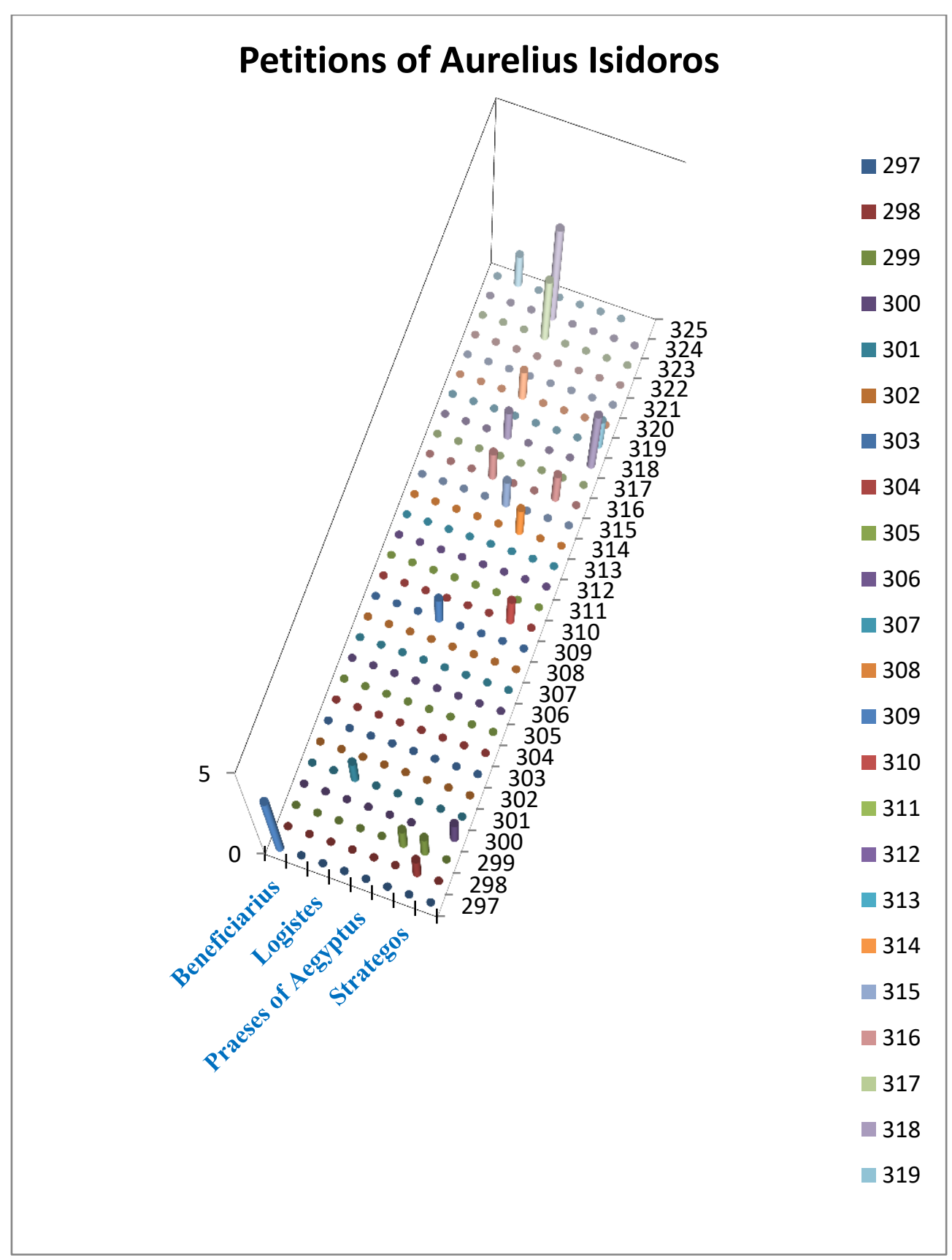

A Chronological Chart of the Petitions of AIPP's Archive 


\section{Magdy A. I. Aly}

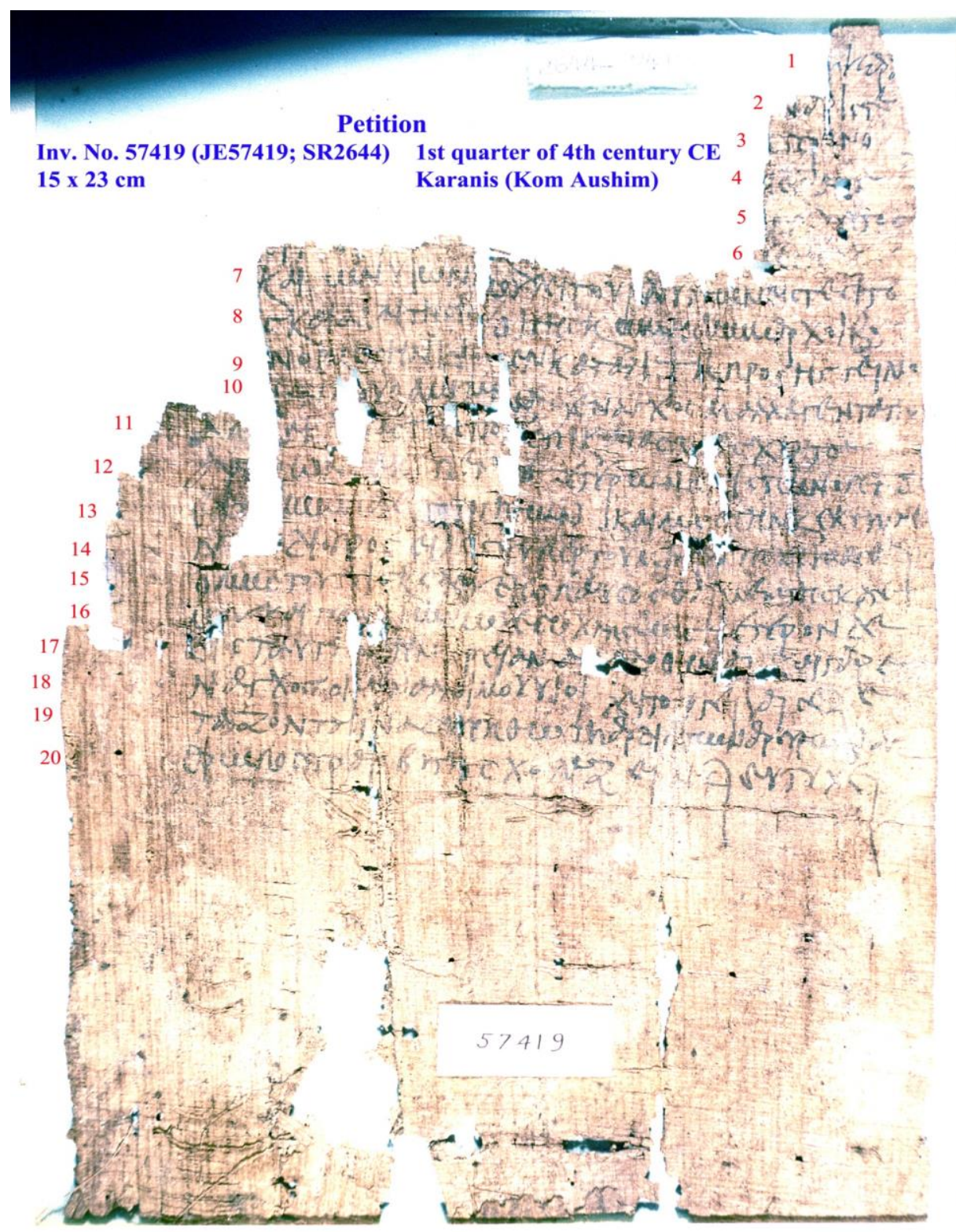

P. CAIR. IsID. 138 


\section{A Petition from P. Cair. Isid}

\section{Key words:}

Archive, Cairo Museum, Greco-Roman History, Greco-Roman period, Greek Language, Isidoros, Karanis, Kom Aushim, Papyri, Papyrology, Petition, Roman Egypt, Roman period, Strategos.

\section{REFERENCES}

- P. Cair. Isid. = The Archive of Aurelius Isidorus in the Egyptian Museum, Cairo, and the University of Michigan, ed. A.E.R. Boak and H.C. Youtie. Ann Arbor 1960.

- P.Col. = Columbia Papyri, New York, Missoula, Atlanta from 1929 to 1989

- P.Mert. = A Descriptive Catalogue of the Greek Papyri in the Collection of Wilfred Merton, from 1948 to 1967

- BOAK A.E.R., Village Liturgies in Fourth Century Karanis, in Akten des VIII. Internationalen Kongresses für Papyrologie, Wien 1955 (MPER N.S. 5), Wien, 1956.

-- / YOUTIE H.C., The Archive of Aurelius Isidorus in the Egyptian Museum, Cairo, and the University of Michigan [P. Cairo Isid.], Ann Arbor, 1960.

- Koenen L. / Omar S., 'P.Cairo Isid. 5', ZPE 111973.

- A.E. Hanson, 'A Petition and Court Proceedings: P.Michigan inv. 6060', ZPE 1111996.

- Minnen Peter Van, Archaeology and papyrology, in Tradition and transformation. Egypt under Roman rule, 2010.

Online Resources:

- PN, Papyrological Navigator. Papyri.info

- TM, Trismegistos, trismegistos.org 